\title{
Measuring the Effects of a Semester Abroad on Students' Oral Proficiency Gains: A Comparison of At-Home and Study Abroad
}

\section{Christopher J. Jochum}

University of Nebraska at Kearney

\section{Introduction}

The effects of study abroad on students' language proficiency have been analyzed using a number of measures such as surveys, questionnaires and oral proficiency exams (Collentine, 2004; Freed, 1995; Segalowitz, \& Freed, 2004). Furthermore, researchers have sought to determine the proficiency gains of study abroad (SA) students by comparing them to those who remained oncampus or at-home (AH) (Félix-Brasdefer, 2004; Hernández, 2010; Isabelli-García, 2010). Although the Oral Proficiency Interview (OPI) and Simulated Oral Proficiency Interview (SOPI) have been used to measure the effects of study abroad (Davidson, 2007, 2010; Freed, So, \& Lazar, 2003; Magnam, \& Back, 2007), a review of the literature reveals that the Oral Proficiency Interview by Computer, the OPIc, has not been used to assess potential proficiency gains. Therefore, the purpose of this study was to measure oral proficiency gains among study-abroad (SA) and at-home (AH) students over the course of one semester, using the OPIc. This study presents a relevant contribution to the literature because (a) it builds upon previous empirical studies designed to assess the effects of a semester-long study abroad experience on students' language proficiency, in comparison to those who remained on campus and (b) uses the OPIc as the measurement instrument. The two primary research questions are: (a) Is there a significant difference in the oral proficiency levels, as measured by the OPIc, between SA and AH students prior to a semester-long study abroad experience? (b) Is there a significant difference in the oral proficiency levels, as measured by the OPIc, between SA and $\mathrm{AH}$ students after a semester-long study abroad experience?

\section{Review of Relevant Research}

Many studies have looked at potential increases in a number of variables associated with study abroad. Overall, results indicate that study abroad does have a positive impact on students' selfconfidence (Allen \& Herron, 2003), self-efficacy (Cubillos \& Llevento, 2013), cultural sensitivity (Martinsen, 2008) and oral proficiency (Davidson, 2010; Hernández, 2010; Lindseth, 2010; Tschirner, 2007).

Another factor related to student achievement during study abroad is the time spent in the target culture. Although a semester-long or one-year study abroad experience is ideal for most college students to reach higher levels of oral proficiency (Swender, 2003), findings related to short-term study abroad (six weeks or less) have been inconclusive. Simoes (1996) found significant gains associated with short-term study abroad while Barfield (1994) indicated that more than six weeks of study abroad is needed to produce measurable proficiency gains. Freed (1990) was unable to 
determine whether or not a short-term study abroad experience was enough to enable participants to produce significant gains in oral proficiency.

Students' living arrangements, which primarily consist of homestays with local families or living in apartments or dormitories, is yet another variable related to study abroad experiences, regardless of the duration of stay. Studies have again shown mixed results. Schmidt-Rinehart and Knight (2004) surveyed students participating in both summer and semester-long programs both pre and post-trip and found evidence that the homestay programs were effective for both groups of students as they reported spending more time interacting in the target language with their host families. Researchers are unsure if homestays are the best option for study abroad students since not all of the family placements encourage students to actively engage in the target language with their host families (Allen \& Herron, 2003; Segalowitz \& Freed, 2004, Wilkinson, 1998; Rivers, 1998). Finally, Magnan, and Back's (2007) study of a semester-long French experience found that living arrangements (host family, dormitory or apartment), did not have a significant impact on students' gains in oral proficiency.

Researchers have also investigated the effects of study abroad on student's language proficiency by either analyzing the SA group pre and post-trip with an "SA-only" design or by administering the same assessments to both the SA group and a comparable group of AH students (pre and post-trip) using an "SA and AH" design. The following reviews will highlight some of the relevant studies that have used these two, prominent designs to assess increases in oral proficiency, using the OPI or the SOPI.

SA-only design. Magnan \& Back (2007) used the OPI (pre and post-trip) to measure the proficiency gains of students participating in a semester-long French program and found that all students $(N=24)$ "at least maintained or increased their proficiency with twelve out of 20 improving one level" (p. 49).

Tschirner (2007) gave German students $(N=15)$ who were participating in a four-week study abroad program the SOPI pre- and post-trip and found that four students did not show improvement, while nine students moved up one level and two students improved two levels.

Martinsen (2008) studied changes in speaking skills that students $(N=45)$ experienced during a six-week study abroad program in Argentina, along with factors that contributed to improvements in their oral proficiency. Pre- and post-trip, students were asked to respond to tasks similar to those used in the OPI. Twenty-two percent either maintained their pre-trip proficiency levels or went up a level which was similar to moving from "Intermediate-Low to almost Intermediate-Mid along the ACTFL (American Council on the Teaching of Foreign Languages) guidelines" (p. 510).

Davidson (2010) reported an ongoing study of students studying Russian in multiple timeframes (two, four and nine months) over a period of 15 years. Multiple measures such as the ACTFL exams in speaking, listening and reading were used to assess potential increases in proficiency gains both pre and post-study. It was found that study abroad had an impact on students' skills with an overall sentiment that that the longer the students spent abroad, the better. However, as the author 
noted, it is still difficult to generalize these findings to other areas with respect to language, time spent abroad and the pre-trip preparedness of the students.

In an ongoing, three-year study, Lindseth (2010) used the OPI to measure the oral proficiency of students $(N=39)$ studying abroad in Germany for one semester. Students were given the OPI both pre-and post-trip. She found that while 31 students showed gains in proficiency, only three reached the Advanced level. In terms of overall improvement, 24 students improved one level, seven improved two levels and another seven showed no improvement (p. 252). As a whole, the overall aggregate mean scores improved from Intermediate Low to Intermediate Mid (p. 253).

SA and AH comparisons. Freed, So, and Lazar (2003) used the OPI to measure the proficiency differences among 15 students studying abroad (SA) in France for a semester and 15 students who spent the semester studying French on-campus $(\mathrm{AH})$. After giving all students the OPI at the beginning and end of the semester, the authors found that the SA students showed significant gains in the rate and content/fluency of their speech. Overall, the SA students "were shown to have made greater progress than the $\mathrm{AH}$ students in both perceived fluency and actual speech features" (paragraph 24).

Segalowitz and Freed (2004) used the OPI to compare proficiency gains (pre/post-trip) among SA $(n=22)$ students spending the semester in Spain and AH $(n=18)$ students who studied Spanish at their home university. In the SA group, twelve students improved their proficiency scores, which was a significant improvement from their pre-trip assessments, compared to the AH group in which only five $(28 \%)$ students increased their scores.

Hernández (2010) also compared the proficiency gains among an AH group $(n=24)$ and a SA group $(n=20)$ who spent a semester in Spain. Pre-trip results on the SOPI did not show any significant differences among the groups. However, at the conclusion of the semester, the SA group showed significant improvement over the AH group with $80 \%$ of the SA students improving at least one proficiency level compared to only $25 \%$ of the AH students who showed improvement (pp. 656-657).

\section{Method}

To determine the extent to which, if any, a semester-long study abroad experience significantly improved students' oral proficiency rating, as compared to their at-home counterparts, the author used a pretest / posttest, quasi-experimental design, which does not include random assignment between the control and experimental groups (Creswell, 2008).

\section{Participants}

Participants consisted of 18 undergraduate students, enrolled at a mid-sized, Midwestern university who were selected during the fall of 2011. Purposeful criterion sampling (Krawthwohl, 1998) was used to select participants who met the following criteria: (1) Spanish major or minor; (2) Native English speaker; (3) No previous study abroad experience; (4) Enrollment in a university-level Spanish class during the fall semester of 2011 and the spring of 2012. 
At-home and study abroad groups. Nine students were assigned to each of the At-Home (AH) and Study Abroad (SA) groups, with each group consisting of two males and seven females $(N=18)$. Participants were enrolled in intermediate to advanced-level Spanish courses and had already completed one to eight semesters of college-level Spanish $(M=3.78, S D=1.80)$. Although the SA group's average number of semesters studying Spanish $(M=4.33, S D=2.12)$ was higher than the AH group $(M=3.22, S D=1.30)$, a one-way ANOVA (analysis of variance) revealed that the averages were not significantly different $(F(1,16)=1.79, p=.199)$. Therefore, the groups were similar with respect to their previous Spanish study and preparation (see Table 1). While all of the AH participants were enrolled in one or more Spanish classes on campus during the fall of 2011 and the spring of 2012, participants in the SA group would spend the spring semester participating in a study abroad program in Lima, Peru where they lived with host families and took four to five Spanish classes, ranging in topics from literature to grammar, at a foreign institution.

Table 1. Comparison of SA and AH Groups

\begin{tabular}{|c|c|c|c|c|}
\hline \multicolumn{5}{|c|}{ Study Abroad (SA) Group } \\
\hline Participants & $\begin{array}{l}\text { Semesters of } \\
\text { College } \\
\text { Spanish }\end{array}$ & Pre-OPIc & Post-OPIc & Gain \\
\hline 1 & 3 & 5 & 7 & +2 \\
\hline 2 & 5 & 4 & 5 & +1 \\
\hline 3 & 7 & 4 & 5 & +1 \\
\hline 4 & 2 & 2 & 5 & +3 \\
\hline 5 & 8 & 5 & 5 & 0 \\
\hline 6 & 2 & 7 & 7 & 0 \\
\hline 7 & 5 & 5 & 6 & +1 \\
\hline 8 & 5 & 5 & 6 & +1 \\
\hline \multirow[t]{2}{*}{9} & 4 & 4 & 5 & +1 \\
\hline & $M=4.33$ & $M=4.56$ & $M=5.67^{*}$ & $\mathrm{M}=+1.11$ \\
\hline \multicolumn{5}{|c|}{ At-Home (AH) Group } \\
\hline Participants & $\begin{array}{l}\text { Semesters of } \\
\text { College } \\
\text { Spanish }\end{array}$ & Pre-OPIc & Post-OPIc & Gain \\
\hline 1 & 3 & 4 & 5 & +1 \\
\hline 2 & 5 & 3 & 5 & +2 \\
\hline 3 & 3 & 5 & 5 & 0 \\
\hline 4 & 3 & 5 & 5 & 0 \\
\hline 5 & 3 & 3 & 4 & +1 \\
\hline 6 & 2 & 2 & 3 & +1 \\
\hline 7 & 5 & 5 & 5 & 0 \\
\hline 8 & 1 & 5 & 5 & 0 \\
\hline \multirow[t]{2}{*}{9} & 4 & 5 & 5 & 0 \\
\hline & $M=3.22$ & $M=4.11$ & $M=4.67^{*}$ & $\mathrm{M}=+.56$ \\
\hline \multicolumn{5}{|c|}{$\begin{array}{l}\text { 1=Novice-Low; 2=Novice-Mid; 3=Novice-High; 4=Intermediate-Low; 5=Intermediate-Mid; } \\
6=\text { =Intermediate-High; 7=Advanced-Low } \\
\text { *Statistical analysis revealed that the SA group's mean scores were significantly higher than the } \\
\text { AH group on the measure of Post-OPIC. All other analyses for mean differences were not } \\
\text { significant. }\end{array}$} \\
\hline
\end{tabular}

\section{Instruments}

Student questionnaire. After participants were selected and assigned to the SA or AH group, 
they responded to a questionnaire which asked them to provide background information such as their gender, college grade level, current Spanish course enrollment, and previous experience studying Spanish.

OPIc exam. In an effort to assess students' proficiency levels more efficiently, both pre-and post-study abroad, the researcher used the computerized version of the ACTFL Oral Proficiency Interview, or the OPIc. Whereas the standard, face-to-face or telephonic OPI has been used for some time, the OPIc is a more recent measure of language proficiency. Despite the online administration of the OPIc, according to the ACTFL's website on the Certified Proficiency Testing Program, "The OPIc is an internet delivered test which provides valid and reliable oral proficiency testing on a large scale...the current version of the OPIc rates the full range of the ACTFL scale, from Novice through Superior" (American Council on the Teaching of Foreign Languages). According to Language Testing International, the company that administers the OPIc, "Research carried out by independent 3rd party analysts shows the OPIc highly corresponds to those issued through OPI. The OPIc has exhibited validity through research on inter-rater reliability, test-retest reliability and construct validity evidence" (Oral Proficiency Interview by Computer).

\section{Procedure}

Pre-trip assessment. To determine the effects of a semester-long study abroad experience on students' oral proficiency, as compared with their at-home counterparts, all participants were given the OPIc exam during the fall of 2011, within six weeks of the SA students' departure. In addition to completing the student survey, the participants took the exam individually in a university computer lab under direct supervision of this study's researcher. All students were informed of their proficiency levels, based upon the ACTFL Proficiency Guidelines (ACTFL, 1999), within two weeks of taking the OPIc.

Post-trip assessment. To assess both groups after the study abroad experience, all participants were once again given the OPIc within six weeks of the end of the spring semester. While it would have been ideal to assess all of the students immediately after the conclusion of the spring term, it was not practical as most of the students were off-campus and unable to take the exam. However, similar to the administration of the first OPIc, all participants were tested on campus under the supervision of the researcher and were given their results within two weeks of completing the exam.

\section{Results}

\section{Data Analysis}

In order to operationalize the proficiency levels and analyze the data statistically, the researched employed a coding scheme consistent with previous research conducted by Hernández (2010) and Hubert (2013). Therefore, the ACTFL Proficiency Guidelines for Speaking were coded as follows: 1=Novice-Low; 2=Novice-Mid; 3=Novice-High; 4=Intermediate-Low; 5=Intermediate-Mid; 6=Intermediate-High; 7=Advanced-Low; 8=Advanced-Mid; 9=Advanced-High; 10=Superior. A statistical software package, SPSS (version 21) was used for all data analyses. 
Research question 1: Is there a significant difference in the oral proficiency levels, as measured by the OPIc, between SA and AH students prior to a semester-long study abroad experience?

Pre-test analysis. The proficiency rating for all participants $(N=18)$ on the pre-test ranged from Novice-Mid to Advanced-Low with an average rating of Intermediate-Low $(M=4.33, S D=1.24)$. Within the SA group, pre-test oral proficiency ranged from Novice-Mid to Advanced- Low, with an average rating of Intermediate-Low $(M=4.56, S D=1.33)$. The pre-test proficiency levels of the AH participants ranged from Novice-Mid to Intermediate-Mid with an average proficiency rating of Intermediate-Low $(M=4.11 ; S D=1.17)$.

To determine if there was a significant difference in the oral proficiency levels between SA and AH students prior to the semester-long study abroad experience, a one-way ANOVA was conducted and did not reveal significance $(F(1,16)=.566, p=.463)$. Therefore, the overall proficiency levels of the two groups were not significantly different before the study abroad experience.

Research question 2: Is there a significant difference in the oral proficiency levels, as measured by the OPIc, between SA and AH students after a semester-long study abroad experience?

Post-test analysis. The post-test oral proficiency ratings for participants in both groups $(N=18)$ ranged from Novice-High to Advanced-Low with an average rating of Intermediate-Mid $(M=5.17$, $S D=.924)$. Among the SA students, post-test proficiency levels ranged from Intermediate-Mid to Advanced-High, with an overall mean rating of Intermediate-Mid $(M=5.67, S D=.866)$. The AH students' post-test proficiency levels ranged from Novice-High to Intermediate-Mid, with an overall proficiency rating of Intermediate-Low $(M=4.67, S D=.707)$.

A one-way ANOVA was conducted to determine if the post-test mean proficiency scores differed between the two groups; results revealed significance $(F(1,16)=7200, p=.016)$. It is also important to note that a series of paired-sample $t$ tests indicated that the pre/post-test improvement was statistically significant within the SA group $(t(8)=-3.59, p=.007)$ but inconclusive within the AH group $(t(8)=-2.29, p=.051)$. The fact that the AH group did show improvement, albeit at a lower level than the SA group, is still encouraging because it shows that the on-campus language instruction that the $\mathrm{AH}$ students received was effective and, overall, enabled these students to improve their average proficiency level over the course of one semester.

Finally, the rate of improvement or the amount that students' proficiency levels increased was also significant among the SA group. Using a coding scheme supported by previous researchers (Brecht, Davidson, \& Ginsberg, 1995; Magnan, \& Back, 2007) each level of improvement (i.e. Intermediate-Low to Intermediate-High) was worth one point. The average level of improvement for all students (within both groups) was almost one proficiency level $(M=.83, S D=8.57)$. More specifically, AH students improved less than one level $(M=.56, S D=.726)$ while SA students improved more than one level $(M=1.11, S D=.928)$. 


\section{Discussion}

The purpose of this study was to build upon previous empirical research in order to assess the effects of a semester-long study abroad experience on students' oral proficiency, as measured by the OPIc. Furthermore, by using a control (AH) and experimental (SA) group, the researcher was able to more accurately determine and quantify the effect of the study abroad experience, as opposed to natural gains in proficiency that could be attributed to Spanish study on-campus.

Although the participants were purposefully selected, the results of the student questionnaire showed that the distribution of students was similar in both groups, especially with respect to their previous amount of university-level Spanish study and pre-test oral proficiency ratings. In fact, the results of the pre-test revealed that the average OPIc rating for both SA and AH students was Intermediate Low. Additional statistical analysis confirmed that the two groups were not significantly different. Therefore, potential differences in oral proficiency among the two groups can be more confidently associated with the effect of the semester-long study abroad experience.

Whereas the results of the first OPIc and student questionnaire confirmed that the two groups were similar prior to the study abroad experience, the post-trip OPIc indicated the positive effect that the semester-long program had on students' oral proficiency, as their average level of Intermediate-Mid was higher than the $\mathrm{AH}$ group average (Intermediate-Low), and revealed a significant increase from the pre-test measures. It is important to mention that while it was not possible to state that the pre / post scores for the AH group improved significantly, there was still growth. This finding is encouraging as it shows that $\mathrm{AH}$ students were still able to improve their oral proficiency through on-campus study. In fact, all but one of the nine (88\%) AH students were at least at the Intermediate-Low level, which was consistent with their related level of Spanish study at the time of the assessment. However, it is important to note that only four of the nine $\mathrm{AH}$ students $(44 \%)$ showed an increase in their oral proficiency.

In contrast, all but two of the SA students (78\%) improved at least one proficiency level, with all students scoring Intermediate-Mid or higher (see Figure 2, below). Moreover, one SA student improved two levels (Intermediate-Mid to Advanced-Low) and another improved three (Novice-Mid to Intermediate-Mid). This rate of improvement (one or more levels) after a semester-long study abroad experience is consistent with similar studies that found improvement rates of 60\% (Magnan and Back, 2007) and 79\% (Lindseth, 2010). Tschirner (2007) studied the effects of a four-week program and found that $73 \%$ improved one or more levels, which is an indicator that at least six weeks of language study is necessary for measurable proficiency gains (Barfield, 1994).

As previously stated, the percentage of students in this study who improved one or more proficiency levels was greater among the SA group than AH students (44\%). These findings are also similar to other studies that used the OPI to measure pre/post improvement among AH students and semester-long SA student. For example, Segalowitz, et al. (2004) found that 53\% of their SA students improved one or more levels, compared to $28 \%$ of the AH students. Hernández (2010) conducted a similar study and reported that $80 \%$ of the SA students improved, compared with $25 \%$ of the AH students. 
Figure 1. Pre and Post Proficiency Levels of At Home Students

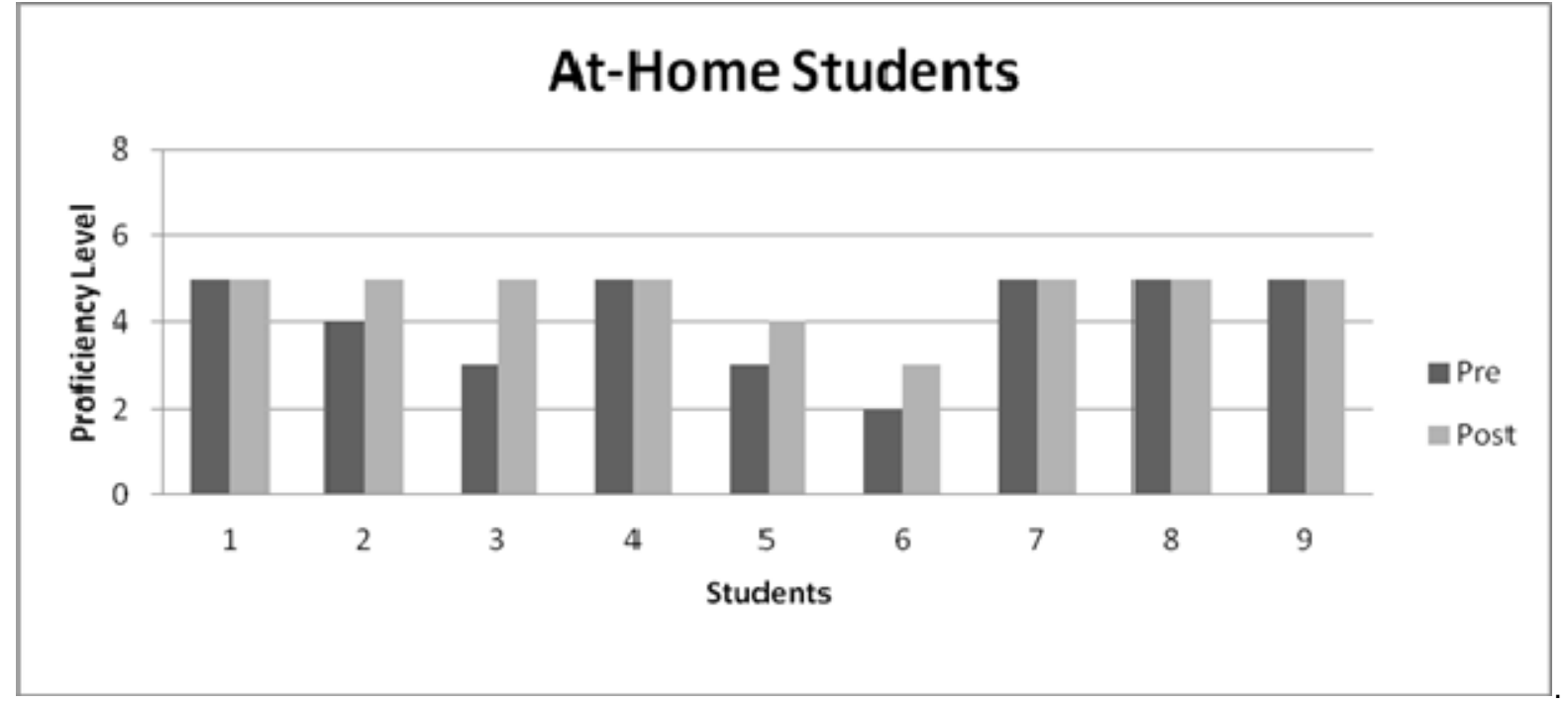

1=Novice-Low; 2=Novice-Mid; 3=Novice-High; 4=Intermediate-Low; 5=Intermediate-Mid; 6=Intermediate-High; 7=Advanced-Low

Figure 2. Pre and Post Proficiency Levels of Study Abroad Students.

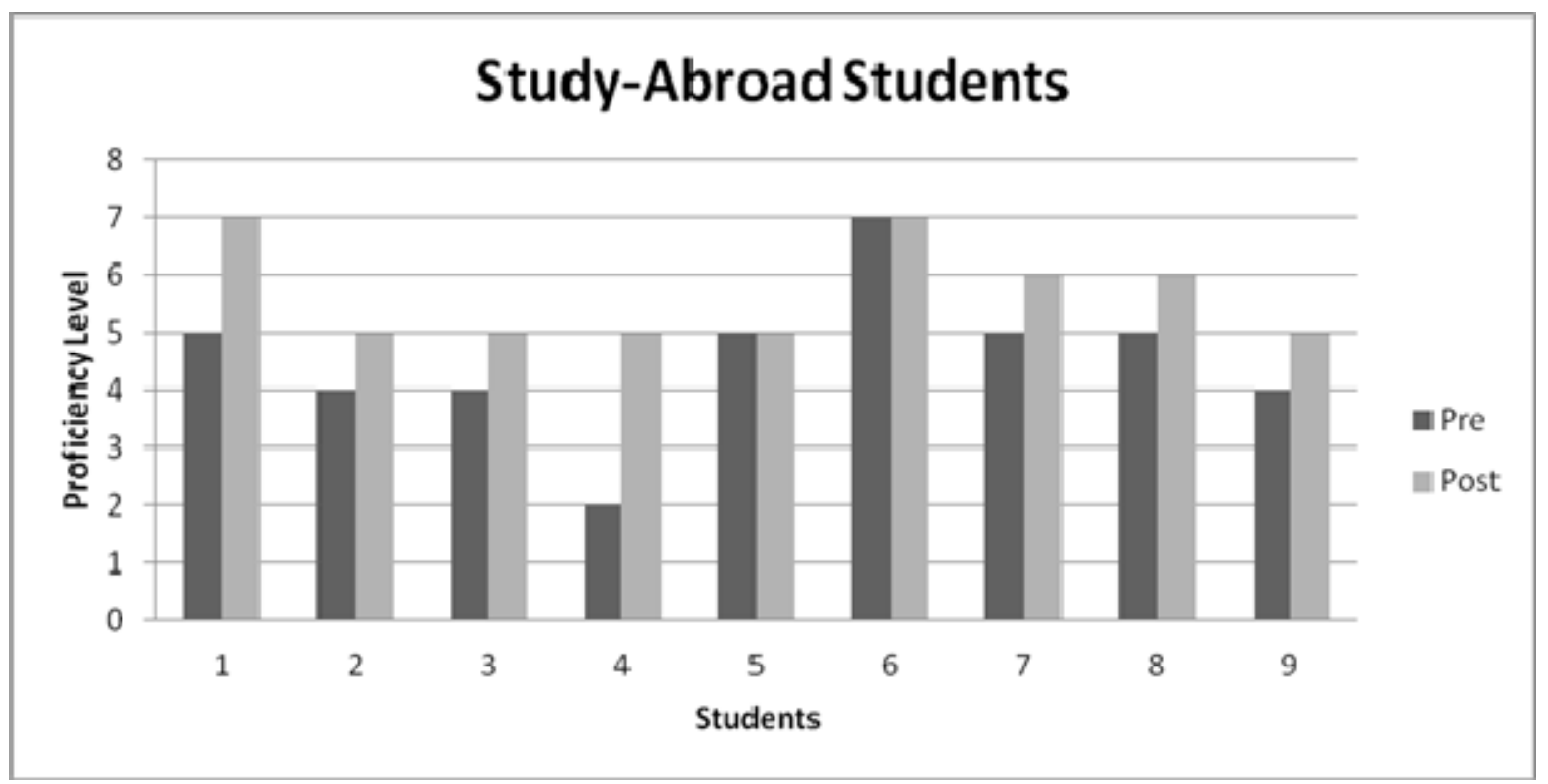

1=Novice-Low; 2=Novice-Mid; 3=Novice-High; 4=Intermediate-Low; 5=Intermediate-Mid; 6=Intermediate-High; 7=Advanced-Low 
The results of this study show the effect of study abroad on students' oral proficiency in the target language (TL). In fact, these findings suggest that students who study abroad for a semester can not only increase their levels of oral proficiency but can do so at a rate that is significantly higher than studying on campus. Overall, this study confidently supports the importance of going abroad in order to achieve higher levels of proficiency.

In addition, this study is an important addition to the growing body of research related to assessing the effects of study abroad on students' oral proficiency because, to date, it is the first to use the OPIc. As previously stated, the OPIc is a valid indicator of proficiency and, due to the online format, it is easier to administer to a large number of students on a continuous basis.

However, these findings are not without critique. One of the more salient concerns is that, despite spending the semester abroad, only two of the nine students were able to reach the Advanced -Low level. This is of particular interest as many areas of language specialization require at least an Advanced-Low level among Spanish speakers, especially for future foreign language educators. For example, the newly-proposed ACTFL/CAEP (American Council for the Teaching of Foreign Languages/Council for the Accreditation of Educator Preparation) Program Standards for the Preparation of Foreign Language Teachers suggest a minimum proficiency level of Advanced-Low for Spanish teachers (p. 15). In addition, the Praxis II (Spanish: World Language), a content-based assessment required for teacher certification in many states (administered by Educational Teaching Services) suggests that candidates have an oral proficiency level of at least Advanced-Low level, per ACTFL guidelines. Therefore, even though the literature does support the notion that both shortterm and semester-long study abroad programs can enable students to improve their language proficiency, it could be that, as Swender (2003) suggested, a one-year study abroad experience is ideal in order to reach the Advanced level.

\section{Limitations}

Although the results of this study provide relevant and applicable insight into the effect of study abroad on students' oral proficiency gains, it is not without its limitations. First and foremost, it should be noted that this study was based upon a small number of students $(N=18)$ that were purposefully divided into the two groups. This was primarily due to the fact that the total number of students participating in the semester-long program was not large. In addition, it was important to find an adequate and comparable control (AH) group, which further inhibited the total number of eligible participants.

Finally, the instrument used to measure students' progress (OPIc) has an associated testing fee and, as a result, the total number or participants were limited to the funding that was available to the researcher as it was necessary to administer a total of 36 OPIc exams.

It should also be noted that because the participants in both groups, especially those that studied abroad, agreed to participate in the study, the results could be slightly skewed. This could be attributed to the fact that, overall, foreign language students who are willing to take a proficiency exam and/or spend a semester studying abroad might naturally be more motivated to study and use 
the language than other students. Therefore, the results of this study and the extent to which they are related to oral proficiency gains in foreign language should be interpreted within the context of study abroad.

\section{Future Research}

In an effort to continue to determine the extent to which study abroad, and its many associated variables, has an effect of language proficiency, future research should continue to investigate the differences between SA and AH students, focusing on large groups or programs that could potentially be studied longitudinally over time. Furthermore, future studies may continue to build upon previous research (Allen \& Herron, 2003; Wilkinson, 1998; Rivers, 1998; Schmidt-Reinhart \& Knight, 2004) related to the effect that students' living arrangements, such as homestays or dormitories, have on their overall ability to improve their language proficiency. It is also important to continue to investigate the variable of time spent abroad and its relationship to proficiency. This is especially important for students such as those going into professional programs, such as foreign language education, who must attain a minimum proficiency level of Advanced-Low. Finally, given the complex nature of language learning and acquisition, it would be illuminating to examine multiple variables, within the same study, in order to determine the most significant factors (instruction, target culture interaction, living arrangements, etc.) related to gains in oral proficiency while studying abroad.

\section{References}

Allen, H. W., \& Herron, C. A. (2003). A mixed methodology investigation of the linguistic and affective outcomes of summer study abroad. Foreign Language Annals, 36(3), 370-384.

American Council on the Teaching of Foreign Languages. ACTFL proficiency guidelines-Speaking. (1999). Yonkers, NY: ACTFL.

American Council on the Teaching of Foreign Languages. (n.d.). Certified proficiency testing program. $\quad$ http://www.actfl.org/professional-development/certified-proficiency-testingprogram\#opi

American Council on the Teaching of Foreign Languages. (2013, August). ACTFL/CAEP program standards for the preparation of foreign language teachers. Alexandria, VA: ACTFL.

Barfield, S. C. (1994). Evaluation of the National Endowment for the Humanities fellowships for foreign language teachers K-12. Washington, DC: Center for Applied Linguistics.

Brecht, R. D., Davidson, D. E., \& Ginsberg, R. B. (1995). Predictors of foreign language gain during study abroad. In B. F. Freed (Ed.), Second language acquisition in a study abroad context (pp. 37-66). Amsterdam: John Benjamins Publishing.

Collentine, J. (2004). The effects of learning contexts on morphosyntactic and lexical development. Studies in Second Language Acquisition, 26, 227-248.

Creswell, J. W. (2008). Educational research: Planning, conducting, and evaluating quantitative and qualitative research. (3rd ed.). Upper Saddle River, NJ: Pearson.

Cubillos, J. H., \& Ilvento, T. (2012). The impact of study abroad on students' self-efficacy perceptions. Foreign Language Annals, 45(4), 494-511.

Davidson, D. E. (2007). Study abroad and outcomes measurements: The case of Russian. Modern 
Language Journal, 91, 276-280.

Davidson, D. E. (2010). Study abroad: When, how long, and with what results? New data from the Russian front. Foreign Language Annals, 43(1), 6-26.

Educational Testing Service. (n.d.). Spanish: World Language. Available: http://www.ets.org/s/praxis/pdf/5195.pdf

Félix-Brasdefer, J. C. (2004). Interlanguage refusals: Linguistic politeness and length of residence in the target community. Language Learning, 54(4), 587-653,

Freed, B. F. (1990). Language learning in a study abroad context: The effects of interactive and noninteractive out-of-class contact on grammatical achievement and oral proficiency. In J. Atlantis (Ed.), Linguistics, language teaching and language acquisition: The interdependence of theory, practice and research (pp. 459-477). Washington, DC: Georgetown University Press.

Freed, B. F. (1995). What makes us think that students who study abroad become fluent? In B. F. Freed (Ed.), Second language acquisition in a study abroad context (pp. 123-148). Amsterdam: John Benjamins Publishing.

Freed B., So, S., \& Lazar, N. (2003). Language learning abroad: How do gains in written fluency compare with gains in oral fluency in French as a second language? ADFL Bulletin, 34(3), 3440. Available: http://www.adfl.org/bulletin/V34N3/343034.htm.

Freed, B., Segalowitz, N., \& Dewery, D. (2004). Context of learning and second language fluency in French: Comparing regular classroom, study abroad, and intensive domestic immersion programs. Studies in Second Language Acquisition, 26, 275-301.

Hernández, T. A. (2010). Promoting speaking proficiency through motivation and interaction: The study abroad and classroom learning contexts. Foreign Language Annals, 43(4):650-670.

Hubert, M. D. (2013). The development of speaking and writing proficiencies in the Spanish language classroom: A case study. Foreign Language Annals, 46(1), 88-95.

Isabelli-García, C. (2010). Acquisition of Spanish gender agreement in two learning contexts: Study abroad and at home. Foreign Language Annals, 43(2), 289-303.

Krathwohl, D. R. (1998). Methods of educational and social science research. New York:Addison Wesley Longman, Inc.

Language Testing International. (n.d.) Oral Proficiency Interview by Computer (OPIc). Available: http://www.languagetesting.com/oral-proficiency-interview-by-computer-opic

Lindseth, M. U. (2010). The development of oral proficiency during a semester in Germany. Foreign Language Annals, 43(2):246-268.

Magnan, S. S. \& Back, M. (2007). Social interaction and linguistic gain during study abroad. Foreign Language Annals, 40(1), 44-61

Rivers, W. P. (1998). Is being there enough? The effects of homestay placement on language gain during study abroad. Foreign Language Annals, 31(4), 492-500.

Schmidt-Rinehart, B. C., Knight, S. M. (2004). The homestay component of study abroad: Three perspectives. Foreign Language Annals 37(2). 254-262.

Segalowitz, N., \& Freed, B. F. (2004). Context, contact, and cognition in oral fluency acquisition: Learning Spanish in at home and study abroad contexts. Studies in Second Language Acquisition, 26(2), 173-199.

Segalowitz, N., Freed, B., Collentine, J., Lafford, B., Lazar, N., \& Diaz-Campos, M. (2004). A 
comparison of Spanish second language acquisition in two different learning contexts: Study abroad and the domestic classroom. Frontiers: The Interdisciplinary Journal of Study Abroad, 10, $1-18$.

Simoes, A. R. M. (1996). Phonetics in second language acquisition: An acoustic study of fluency in adult learners of Spanish. Hispania, 79, 87-95.

Swender, E. (2003). Oral proficiency testing in the real world: Answers to frequently asked questions. Foreign Language Annals, 36(4). 520-535.

Tschirner, E. (2007). The development of oral proficiency in a four-week intensive immersion program in Germany, 40(2), 111-117.

Wilkinson, S. (1998). Study abroad from the participants' perspective: A challenge to common beliefs. Foreign Language Annals 31(1), 23-39. 